\title{
Cidade brasileira. Przestrzenie skrajności
}

\section{Cidade brasilleira. Spaces of Extremes}

\begin{abstract}
Streszczenie
Brazylia. Fawele i perfekcjonistyczne budynki Oscara Niemeyera. Terra incognita i wyobrażenie. W brazylijskiej interpretacji kosmopolityczny modernizm stał się emocjonującym, lokalnym „modernizmem brazylijskim”, łączącym cechy rdzenne z uniwersalnymi. Mimo to, schedą idei modernizmu okazały się też przestrzenie obce i nieudomowione, zaś alternatywą społeczną okazały się favelas. Powstały obszary rozerwane i niespójne, tereny bogactwa i biedy, tworzące przestrzenie do życia pełne skrajności. Władze miejskie podejmują próby odzyskania wykluczonych terenów, a projekty objęły analizę funkcjonalno-przestrzenną i próbę jej restrukturyzacji poprzez działania miejscowe.
\end{abstract}

\begin{abstract}
Brazil. Favelas and Oscar Niemeyer's perfectionist buildings. A terra incognita and an idea. In its Brazilian interpretation, cosmopolitan modernism became an exciting, local "Brazilian modernism", one that combines native characteristics with universal ones. Despite this, alien and untamed spaces have also become a legacy of the idea of modernism, while favelas have become a social alternative. Torn and inconsistent areas have been created, areas of affluence and poverty, creating spaces for living that are replete with extremes. Municipal authorities are making attempts at reclaiming key areas, and projects have included functional and spatial analyses as well as attempts at restructuring them through local actions.
\end{abstract}

Słowa kluczowe: Modernizm, fawele, Niemeyer, Brazylia

Keywords: Modernism, favelas, Niemeyer, Brazil

\section{Wprowadzenie}

Brazylia. Terra incognita i wyobrażenie. Brazylia to zieleń, święta przestrzeń natury, tzw. płuca świata i ich zagrożenie przez lokalny rozwój handlu olejem palmowym. To destynacja modnych wycieczek, kuszących zetknięciem dzikiego mitu Ameryki Południowej, sensualnej konsumpcji (samba) i nowoczesnych miast budowanych na osi skrajnej biedy i bogactwa. To fawele i budynki Oscara Niemeyera. To znane dźwięki Caetano Veloso, piłka nożna i wielkoskalowe instalacje Ernesto Neto. To też wyprawy Mariny Abramović. I Jair Bolsonaro, który tworzy dziś jeszcze bardziej zagadkowy wizerunek tego kraju. To miliony ludzi, dla których synonimem domu są przepełnione, chaotyczne favelas. Brazylia to tygiel wrażeń i wyobrażeń, które kultura jej przypisała, to skrajności, których tropem wciąż wyruszają kolejni badacze.

Wielu badaczy i turystów rusza do Brazylii jednym z czołowych jej tropów - tropem natury. Amazonia, nawet przy rozwiniętych machinach przemysłu turystycznego, wciąż pozostaje terenem niezbadanym, fascynującym, a miejscami - nawet niebezpiecznym.

Natura to też przestrzeń, pozornie, bez historii. Przestrzeń nietknięta i ocalona. Ten pozór w Brazylii ma znaczenie szczególne. Na terenie czystej ziemi Ameryki Południo-

\section{Introduction}

Brazil. A terra incognita and an idea. Brazil is greenery, a holy space of nature, the so-called lungs of the world and the danger posed to it by the development of the local palm oil trade. It is a fashionable tourist trip destination, which entices us with its combination of the wild myth of South America, sensual consumption (samba) and modern cities built at the axis of extreme poverty and extreme affluence. It is also the favelas and Oscar Niemeyer's buildings. It is the well-known sounds of Caetano Veloso, football and large-scale installations by Ernesto Neto. It also encompasses the expeditions of Marina Abramović. And Jair Bolsonaro, who now creates an even more enigmatic image of the country. It is millions of people, who call the overcrowded and chaotic favelas their home. Brazil is a melting pot of the experiences and ideas that culture has ascribed to it, it is the extremes that are the pursuit of more and more scholars.

Many scholars and tourists go to Brazil by following one of its major trails - that of nature. The Amazon, even when faced with the developed machinery of the tourism industry, still remains a place that is uncharted, fascinating, and even dangerous in some places. 

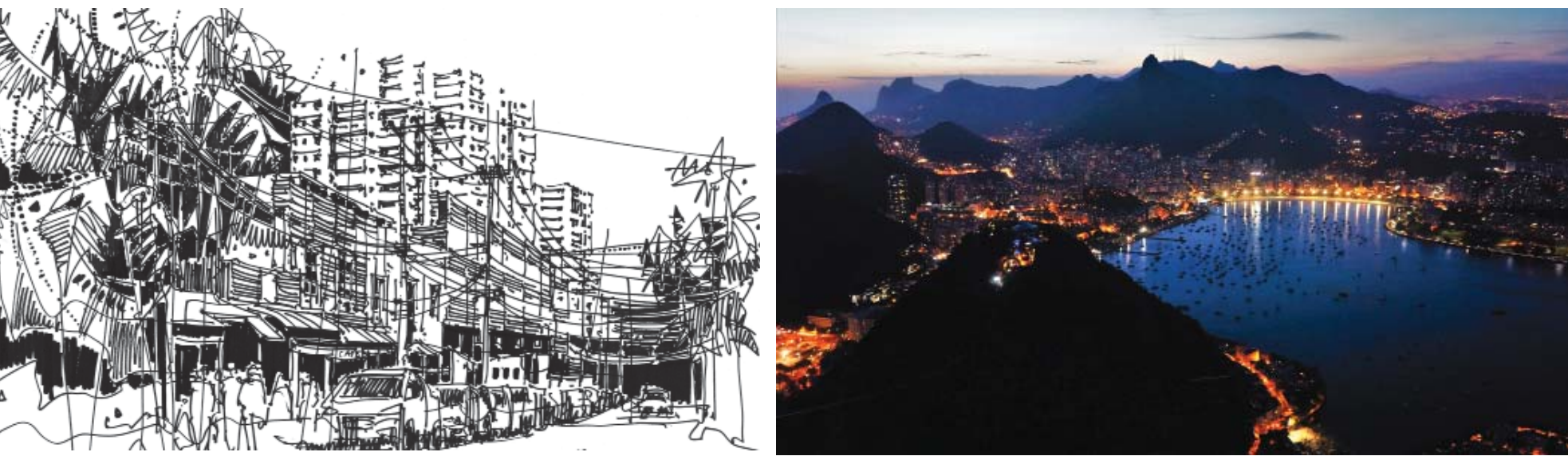

II. 1. São Paulo, fragment ulicy w dzielnicy mieszkaniowej; rys. B. Malinowska-Petelenz / São Paulo, fragment of a street in a housing district; by

B. Malinowska-Petelenz
I1. 2. Rio de Janeiro, widok na miasto z Gtowy Cukru; fot. B. Malinowska-Petelenz / Rio de Janeiro, view of the city from Sugarloaf Mountain;
phot. B. Malinowska-Petelenz

wej, silnie zamanifestowała się destrukcyjna moc historii i kultury. Dziś więc, nawet przestrzenie natury nietkniętej, skażone są już znaczeniami nie-obecności - tę dzikość i nature jadą oglądać syci turyści zachodniego świata. I w te przestrzeń paradoksu i zmonetyzowanych niemierzalnych znaczeń przez lata wchodzi artystka i performerka - Marina Abramović. Jak sama wspomina w autobiografii „Pokonać mur"1 - Brazylia była dla nie jednym z celów i etapów osobistej podróży i rozwoju. Abramović, przez lata cwiczaca się $w$ duchowej dyscyplinie (np. w Brazylii i Australii), podsumowuje te praktyki w filmie "Space in between". Tu Brazylia staje sie kolebką rytuału, jako zdarzenia transformującego, spajającego duchowośc z rzeczywistością. Artystka, znużona konsumpcjonizmem zachodniej cywilizacji, probujow dzikiej ziemi, wśrod ludzi dla ktorych to natura jest domem, odnaleźc ukojenie i pierwotną energię. Zdaniem Mariny Abramovic funkcja ponformansu irytuału jest podobna - ma zmienic uczestnika, dac odbicie od powszedniosci i zozliwosc spojzznia dac od oczami. Jak mowi "Natura nie potrzebuje sztuki. Sztuki potrzebujemy w miastach: dusznych, głośnych, zanieczyszczonych, w miastach, w ktorych nie mamy czas na duchowość - sztuka tworzy tę szczelin

Jednym z takich miejsc, wyrosłym w tyglu wrażeń, moż liwości i wizerunkow, jest miasto-hybryda. Miasto stwo pierze. Brasilia.

\section{Brasilia: sen i rzeczywistość}

Brasília - stolica, przestrzeń „oswojona i niezwykle młoda. Wszak nie istniała jeszcze na poczatku XX wieku. To kwintesencja myśli modernistycznej na gruncie latynoamerykańskim. Kultowe miasto spod znaku Ruchu Nowoczesnego jest jednym z niewielu przykładów idei zmaterializowanej - miasta utopii. Projektantami nowej stolicy Brazylii zostali Lúcio Costa i Oscar Niemeyer. Pierwszy z nich odpowiadał za układ przestrzenny, drugi -za architekture miasta. Precyzyjnie Kubitchka: miastem wzorcowym i symbolem nowej
Nature is also space, one that seemingly has no history. An untouched and saved space. This appearance is of special significance in Brazil. The destrucwith a particular strength in the pure land of South America. Today, even untouched natural areas are well-fed tourists from the western world that is the

And it is this space of paradox and monetised, immeasurable meanings that the artist and performer Marina Abramović has been entering for years. As she he self mentioned in her autobiography "Walk Through Walls" - to her, Brazil had been one of the goals and Abramović, who had trained her spiritual discipline for years (e. Here, Brazil becomes the birthplace of the ritual, seen as a transformative event that binds spirituality with reality. The artist, tired of the consumerism of western wild land, among people to whom nature is their hom this According to Marina Abramović, the functions of performance and ritual are similar-they are intended to change those who participate in them, tear them away from mundanity and enable them to look at themselves through different eyes. She claimed that nature did not need art, that we needed art in our cities: that were time for spirituality, and that art created this gap ${ }^{2}$. The hybrid city is one of those places, grown from a melting pot of experiences, possibilities and imges. A city created not from the heart and need of the people, but from reason and on paper. Brasília.

Brasilia: a dream and a reality

Brasilia-a capital, a space that is domesticated and remarkably young, even though it did not exist at the modernist thought in Larty. It is the quintessence Modern Movement, it is one of the few examples of the manifestation of an idea-a utopian city. Lúcio Costa and Oscar Niemeyer became the designers of ayout, while the second-for the city's architecture. watch its wildness and nature. practices in the film entitled "The Space in Between" myśli modernistycznej, swiadectwem dekolonizacji r odcięcia się od portugalskiego Wybreza. Miala być tez początkiem zjednoczenia wielokulturowego mocarstwa. 21 kwietnia 1960 Brasilia oficjalnie stała sie stolicą Brazylii i jest nią do dzis.

Brasilię zaprojektowano i podzielono zgodnie $z$ modernistycznymi zalożeniami na róñe sektory. Wzdłuż dłuzszej osi - na linii skrzydeł - usytuowan. dzielnice mieszkaniowe, a wzdluź krotszej zlokalizowano obiekty rządowe, administracyjne oraz użytecznośc publicznej. Otoczone mialy byc strefami hotelowym komercyjnymi. Zabudowa mieszkaniowa miasta zostala podzielona na osiedla - superquadra - sześciopiętrowe ploki z own parterem, waz z podstawowym Jena

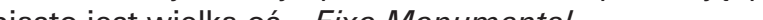

Architektura i urbanistyka może gloryfikować osobę dyktatora i wtraczać jednostkę w masęé. O Eixo Monumenmożna powiedzieć, że jest kwintesencja absolutyzmu politycznego - wszak to one geometryzują i porządkuja scenografię miejską właśnie poprzez wprowadzenie os i coraz wiekszej siatki równoległych i prostopadtych. W Brasilii widoczne jest zróżnicowanie pomieadzy prze strzenia dla władzy - prestiżowa i bogata - a przestrze nią dla ludzi - uboga i substandardowa. Trudno uniknaç skojarzeń z mentalnością kolonialna, która charakteryzuje pogarda dla zwykłych mieszkańców. Costa z Niemeyerem tworzą swoisty brazylijski Akropol - wzorujac sie na corbusierowskim Chandigarh - wynosza go na wielka płytę ze sztucznego terenu, tym samym manifestacyjnie odrywają strefę władzy od strefy „podwładnych" Brakuje tu rozgadanych ulic i placow, czyli najwazniejszych komponentow struktury miejskiej. Nadmiar przestrzeni, swiatla i powietrza zabil podstawowy budulec istoty miejskosci przestrzenie publiczne - miejsca spotkan, wymiany i komunikacji. Pozostały przestrzenie zawhaszczone przez samochody. Przestrzenie opuszczone w których zycie publiczne zamarło, a segregacja funkcj i poszczególnych dzielnic pociągnęeła za sobą segregację spoleczną. Dzisiejsza Brasilia sąsiaduje więc $z$ nędza fawell - 2,5 mln mieszkańców stolicy boryka się z tym samymi problemami, co mieszkancy inych miast. Bogaci Wznoszą rezydencje po drugiej stronie sztucznego jeziora para reá, zasisich rzech Wadz jest miejscem demonstracji brazylijkich kobiet, Indian i robotnikow ro-

w pobliżu jednego budynów brazylijskiego modernizmu -
Planned with precision - it was meant to be president Juscelly Kubischek's dream: a model city, a symbol of new modernist thought, a testament to coast It was also meant to be the beging Portuguese unifiction of a multi-cultural power. On the $21^{\text {st }}$ of April 1960, Brasilia officially became the capital of Brasilia was designed and divided into different sectors in accordance with modernist assumptions. Residential districts were placed along its longer axis-along the line wits wings-while government placed along the shorter one. They were meant to be surrounded by hotel and commercial zones. The city's housing developments were to be divided into quarters-superquadra-six-storey blocks with an open ground floor, which, along with essential services were to form a system of neighbourhood units. ever, the most important element that was meant to Architecture and urban planiing can glorify a dictitor and push the individual into the multitude 4 . Eixo Monumental can be described as the quintessence of political absolutism-all in all, it is these elements that geometricise and provide structure to urban scenography by introducing axes and an increasingly we can of the differences between the space for the government-prestigious and affluent-and the space for the people-poor and substandard. It is difficult to avoid associations with a colonial mentality characterised by contempt for ordinary residents. Costa and Niemeyer created a Brazilian Acropolis of sorts-by using Corbusier's Chandigarh as a model, simultaneously detaching the sphere of the government from the sphere of its "subjects"

There is a lack of bustling streets and squares here-the most important components of an urban structure. The excess of space, light and air has killed the fundamental building block of the essence meet exchange ideas and communicate. Pny plaples dominated by cars have remained Deserted spaces, where public life has died out and the segregation of functions and individual districts has led to socia segregation. Contemporary Brasilia borders on the poverty of the favelas- 2,5 million of the city's residents face the same problems as the residents of other cities. The wealthy build residences on the othe
side of the artificial Lake Paranoá, while Three Powers Square is a place where Brazilian women natives and landless farm workers stage their protests.

II. 3. Rio de Janeira, fawela; rys. B. Malinowska-Petelenz / Rio de Janeira, favela; by B. Malinowska-Petelenz
II. 4. Brasilia - widok fragmentu Eixo Monumental (katedrai Museu Nacional da Republica, proj. . Niemeyer); fot. B. Malinowska-Petelenz /
Brasilia - view of a fragment of Eixo Monumental (cathedral and Museu Nacional da Republica, design by O. Niemeyer); phot. by B. Malinowska-
-Petelenz

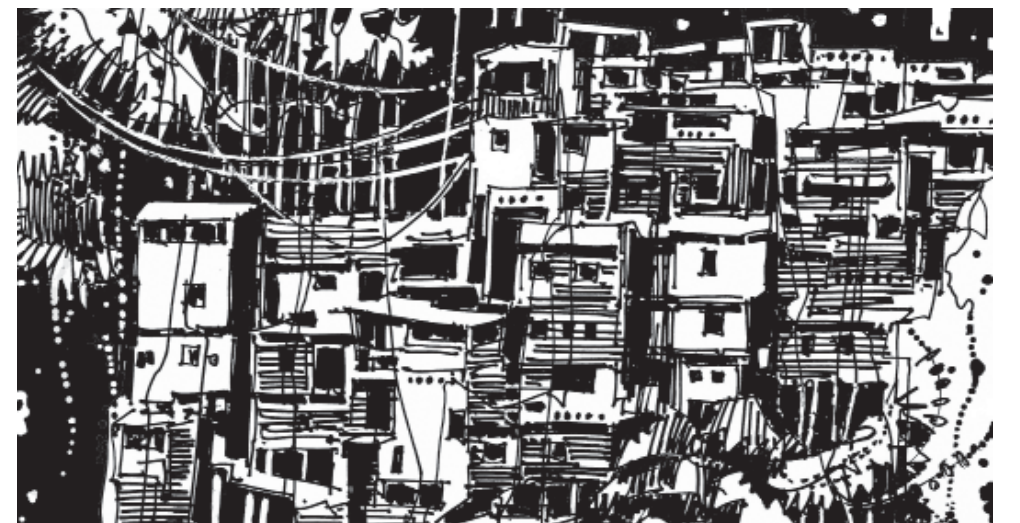

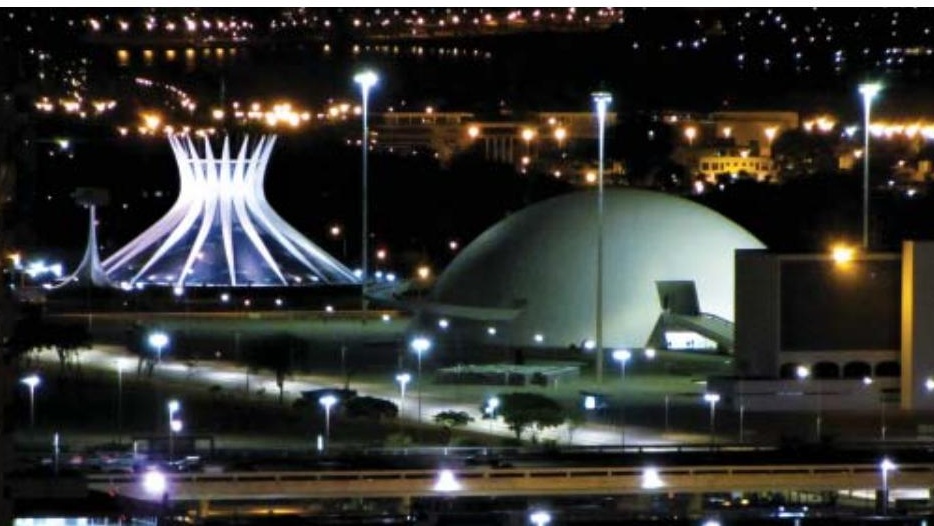


Historia i eksperyment
Rdzennym mieszkańcom terenów dzisiejszej Brazylii, mimo przemocy i kolonizacji portugalskiej, udało się
ocalić kulturę, obyczaje i poczucie odrębności wspólnotowej. Do tej właśnie architektury i oryginalnej mieszank kulturowej odnieśli się później młodzi moderniści, szukający korzeni i lokalnej tożsamości. W ich interpretac kosmopolityczny modernizm stał się emocjonującym brawurowym, rodzimym "modernizmem brazylijskim", łączącym cechy lokalne $z$ uniwersalnymi. To m.in. $z$ tradycji kolonialhe jwięla się jedna z czolowych cech archtektury brazylijskiej - typowa dla portugalskiego barok fasadowość i przywiązywanie wagi do dramatyzowani formy zewnettrznej"

Szkola Rio jak i Szkoła Paulista13 (będąca wypadkow Ruchu Nowoczesnego w wydaniu europejskim, jak i półkonduit brazylijskiego narodu, tworzac architekturowa woczesna lecz jednoczénie rizenna i rodzima I no architektura ta wyrosta w opozycji do architektury kolo nialnej, nawiazywała do niej w znaczacy sposób. Olśnie wająco białe tynki, szafirowe azulejos i drewno - to ele menty zidentyfikone przez społeczeństwo - to elejako własne i wchłonięte do współczesnego alfabk jako wiasne i wohiton

Brazylijski dom to kolor, faktura i zieleń. Barwy ziemi, czernie, żółcienie, a także granat, ultramaryna i soczyst zieleń roślin w połączeniu z białymi tynkami, płaskorzeźbami i sgraffitami tworzą znaczący element tożsamościowy, kwintesencję brazylijskości. Także zastosowanie żywiołów: powietrza, wody i zieleni w głębi struktur architektonicznych przez wznoszenie brył poderwanych od ziemi na poziomie parteru jest tu powszechne. Łączność z podłozem oprócz słupów zapewniają jedynie trzony komunikacyjne. Ale w Brazylii ów formalny, znany, uniwersalny chwyt nabiera lokalnego i szczere go charakteru. To tradycyjne palafitas - stosowane do dzis przez Indian amazonskich żjących nad rzekam i chroniących się od ich wylewów - ktore znajdują swe odzwierciedlanie w betonowych, stojących na słupach obiektach mieszkalnych i użyteczności publicznej. Wy starczy wspomnieć ikoniczny już budynek MES w Rio lub jednostek Superquadra $W$ Brasilii, a także projekty klasykow. Liny Bo Bardin, João Batisty Vilanova Artiga$\mathrm{sa}^{15}$, Jose Oswalda Vilela ${ }^{10}$, Paula Mendesa da Rocha ${ }^{11}$ Ruya Ohtake" Álvaro Puntoni 20 , tsay Weinfeld 21 , presownie

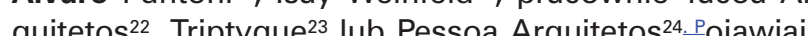
sie tu stupy podpory inne elementy pozwalajace wpuścić do środka wode powietrze i niezwykta, tropikalna zieleń $W$ ten sposób obie sfery - wnetrze i zewnetrze - przenikaja sie wzajemnie, tworzac splot kontrastów które zawsze powstają na styku kultury i natury. Rozwój architektury to też historia brawurowej myśli i eksperymentu, które przebiegały zwykle spektakularnie, zwłaszcza te dotyczące modeli osiedleńczych i funkcjonalnych. Przeniesione do skali rzeczywistej bywaty jednak boleśnie weryfikowane. Brytyjskie prototypy miast ogrodów, Chandigarh, nawet renesansowa Palmanova nigdy nie stały się dla potencjalnych mieszkańców
The native inhabitants of contemporary Brazil have Poir sense of communal separateness despite Portuguese violence and colonisation. It is to this modernists later referred to when searching for their roots and local identity. In their interpretation, cosmopolitan modernism became a stimulating dashing, native "Brazilian modernism", which combined local and universal characteristics. It is from colonial tradition, among other things, tha ine of the major features of Brazilian architecture typical of the Portuguese Baroque and the stress placed on a dramatic external form 11 .

The Rio ${ }^{12}$ and Paulista ${ }^{13}$ schools (which arose from the Modern Movement in its European and North American versions) combined with the multi-cultural conduit of the Brazilian nation, creating an architecture that is although this architecture arose in opposition to lonial architecture, it referenced it to a significant degree. The gleaming white plasters, the emerald azuleos and timber-are elements that are identified by Brazilian society as its own and have been absorbed into its contemporary architectural alphabet.

The Brazilian house is colour, texture and greenery The colours of the earth, blacks, yellows, as we plants, when combined with white plaster, reliefs and
phave graffito, create a significant identity-related element, the quintessence of Brazil. The use of the elements: air, water and greenery deep within architectura structures by erecting massings that stand on columns at ground-floor-level is widespread here. The columns, solely by circulation cores. But in Brazil, this formal, well-known and universal measure takes on a local and genuine character. These are the traditional palafitas - which remain in use by Amazon natives who live near rivers and which protect them fom columns. The iconic MES building in Rio or the $S u$ perquadra housing units in Brasília are sufficient examples of this, as are projects by the classics: Lina Bo Bardi'14, João Batista Vilanova Artigas ${ }^{15}$, José Oswald Vile ${ }^{16}$, Paulo Mendes da Rocha'17, Ruy Ohtake ${ }^{18}$, Han

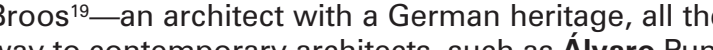

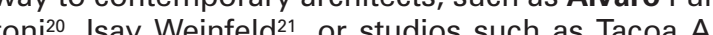
quitetos ${ }^{22}$. Triptyque ${ }^{23}$ and Pessoa Arquitetos24. We can see columns, supports and other elements that make it possible to let water, air and remarkable trop cal greenery inside. In this manner, both spheresthe interior and the exterior-blend with each other creating a weave of contrasts that are always created The development of architecture is also a history of bold thoughts and experiments, which were usually spectacular, particularly those concerning settlement and functional models. When carried over into reality they were sometimes painfully verified. The British prototypes of Garden-cities, Chandigarh, even the Renaissance Palmanova never became magnets for that subverted the principles of traditiousing estates property attract architects or architecture students magnesami, zas nowatorskie osiedla mieszkaniowe podwazające zasady tradycyjnego strefowania i własnoś przyciagaja dzis co najwyzej architekow lub studentón architektury. Nawet fascynująca poznawczo Jednostk Marsylska dobrym miejscem do mieszkania raczej nie jest... nawet jako edukacyjny hotel, na jedną dobę Przykładem takiego wielkomiejskiego i kontrastowego architektonicznego eksperymentu kulturowo-tożsamościowego jest najwazzniejsza i najbardziej reprezentacyjna ulica w innym brazylijskim mieście - São Paulo Avenida Paulista, uważana za najdroższą ulicę Amery Poludniowej. Obecnie porównywana jest do nowojor skiej Piątej Alei lub paryskich Champs-Elysees, niegdy przypominala polwejski bu war z wysafnowany

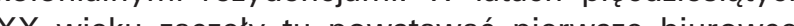
a w wach széćctriesiatych stata sie wielkim centrum biznesu. Dziś, zarónita gaszczem banków, biurow ców i siedzib instytucji korporacyinych i kulturalnych, jest sercem miejskiej dżungli, której melanż formalny zaskakuje i wprawia w zdumienie. Obok dawnych ma tych, kolonialnych, białych perełek wyrosty dziesiatk kolosów od klasycznych Edifício Palácio Quinta Ave nida ${ }^{26}$ i Edifício Paulicéia ${ }^{27}$, przez hybrydowy Conjunto Nacional28, Galerie FIESP29 lub nainowsza Paulista Tower $^{30}$. Na zamknięciu perspektywicznym tej wielkiej os powstała w 2008 roku charakterystyczna "brama" - To Towers ${ }^{31}$ złożona z bliźniaczych dwóch budynków, jed na $z$ najdroższych wież mieszkalnych $w$ mieście ${ }^{32}$. Wyrosła obok słynnej „złotej” prawosławnej katedry, majestatycznej i całkowicie tradycyjnej w swym dekorze powstałej w połowie XX wieku.

\section{Bogactwo i bieda}

Miniony, XX wiek, to czas zmian, także w Ameryce Połudiowej z mian spolecznych, gospod vir nicznych. Pochód modernistycznej utopii powołał do zycia $z$ jednej strony miasto interesów, miasto szybkosci, miasto sukcesu, z drugiej - swoisty, dystopijny, urbanistyczny komentarz $z^{33}$. Dwie gigantyczne metropolie - Sao Paulo i Ri de Janeiro - to miasta "pęknięte", wypełnione zarówno ekskluzywną architekturą, obiektami kultury i sztuki oraz najnowoczesniejszymi budynkami mieszkal isi, ale takż

Peru nazywa się je pueblos jovenes, w Chile - callampas, , zaś w Argentynie - villas miserias - miasta nędzy. W Bazyary ó́rodków miejskich sa efektem tego sakego procesu - dramatycznej migracii ludności do mist która rozpoczeta sie w potowie ubiegtego wiek ${ }^{34}$. Rio de Janeiro znajduje sie w czotówce miast o najwyższych kosztach życia i wysokich nierównościach społecznych. Mówi sie, zie to miasto rozciete, podzielone. Tu sasia duia ze soba domy biedoty i luksusowe apartamenty - odgrodzone od siebie płotem z kamerami. Przed mistrzostwami świata w pitce nożnej w 2016 roku, tereny okołostadionowe nie tylko poddane były znaczacym weryfikacjom, takim jak wysiedlenia, ale i modernizacje niektórych rejonów favelas.

Dzisiejsze favelas - to gigantyczne, nieformalne struktury osiedlowe, rozrastające się zarówno na obrzeżach jak at most. Even the cognitively fascinating Unite d Habitation in Marseilles is not too good of a place Another exas an educational hotel for a day "stay". Another example of such a big-city and contrasting the most important and most representative stree in a different Brazilian city- São Paulo-Avenid of South America. It is compared with New York's Fifth Avenue or Paris' Champs-Élysées, though it once resembled a semi-rural boulevard with sophisticated colonial residences. The first office buildings started it became a significant business centre. Today overgrown with banks, office buildings and corporate and cultural headquarters, it is the heart of the urban jungle, whose formal melange is both surprising and amazing. Tens of colossi have sprouted in the vicinity of the small historical colonial gems, ranging Avenida $2^{26}$ and the Edifício Paudifício Palácio Quin Avenida $a^{26}$ and the Edifício Paulicéia $a^{27}$, to the hybrid
Conjunto Nacional ${ }^{28}$, the FIESP Gallery Paulista Tower ${ }^{30}$. A distinct "gateway" was built at the culmination of this grand axis in 2008-the Top Towers complex ${ }^{31}$, composed of twin buildings and one of
the most expensive residential towers in the city ${ }^{32}$. It was built right next to the famous "golden" Orthodox
cathedral from the middle of the twentieth century, which is majestic and fully traditional in its decor.

\section{Affluence and poverty}

The twentieth century was a time of change- of social, economic and architectural change-and South America was no exceptio. The march of the modernist
utopia brought to life a city of business, speed and success on the one hand, and a sort of dystopian urbanist commentary on the other $^{33}$. Two gigantic "cracked" cities, filled with exclusive architecture as well as buildings of culture and art and the latest in modern residential buildings, but also with entire districts dominated by poverty, hunger and crime. ampas - while in Argentina - villas min Chile-caof misery. In Brazil they are called favelas. Although are the result of the same process-a dramatic migration to large cities which has started in the middle of the previous century ${ }^{34}$. Rio de Janeiro is among the leading cities in terms of living costs and stark that has been cut, that has been divided. Here the houses of the poor stand beside luxury apartment buildings-walled off from each other with fences and cameras. Prior to the football world cup of 2016, the areas around stadiums as well as elsewhere, were subjected to considerable verifications, such as in soment campaigns and moc

structures, spreading both on the outskirts of and in the inner cities, inhabited by the poor and those who have been cast out for various reasons: be it class, race, ethnicity or money. Favelas are characterised by spaces and low development density, a lack of ope remaces and biologically active surfaces, in addition to on the outskirts of cities, they "poured" into their 
względem wielkości dzielnica slumsów położona w są-zachodniej części São turyzowana dzięki scisłej wspołpracy miasta z lokalnym społecznościami. Powstające za miejskie pieniądze nowe budynki w miejscu zniszczonych ruder sa sprzedawan mieszkańcom na raty. Powstające od kilku lat nowe budynki są utrzymywane $w$ bardzo dobrym stanie, zadbane $z$ wypielęgnowaną wokó zielenią. W ramach projekt unowocześniono siec dystrybucji energii elektrycznej, funkcjonuje komunikacja zbiorowa, powstały sklepy, szpital, szkoła i boiska pilkarskie. Mieszkańcy wykazują duż aktywnosc i rowniez sami rozwijaja swoje nieformaln miasto ${ }^{45}$. Dla kontrastu $-w$ sąsiedztwie zlokalizowane sa trzy wieże mieszkalne, jedne z najdroższych w mieście. Każda kondygnacja zawiera jeden apartament wyposażo-
ny w duży taras i własny basen, skąd roztacza się fascyny w duży taras i własny basen, skąd

nujący widok na fawelę Paraisopolis.
Pomimo swej grozy fawele są na swój sposób piękne Pomimo swej grozy fawele są na swój sposób piękne. Radykalnie piękne. To właśnie one są fascynującym źród-
tem twórczości literackiej, malarskiej i filmowej. Ich ekspresyjna struktura przywodzi na myśl osiedla budowane presyjna struktura przywodzi na mysl osiedla budowane
przez Indian Pueblo w Nowym Meksyku i Arizonie. Tak w pierwszym jak i drugim przypadku mamy do czynienia z budownictwem tarasowym, w którym dachy "starszej warstwy" domów stanowia podstawe dla kolejnych budynków. Swoista spektakularność, pozorny chaos i bezlik form, przypadkowe zagęszczenia i zmieszanie kształtów składaja się na szczególną plastyczność i obrazowość struktur favelas. Zestawienie zmiennych, rozlewajacych się, piętrzących pudetek o nieregularnych, miękkich granicach z monstrualną architektura wysokich budynków - form mocnych $i$ "twardych" - generuje niespotykane, wręcz porażające zjawisko kontrastu, tym samym wywołujac u obserwatora z jednej strony lek i świadomośc społeczna, z drugiej: zachwyt i wstrzas estetyczny ${ }^{46}$. Fundamentalnym walorem favelas jest ich jednorodność strukturalna, która ma kluczowe znaczenie dla odbior spójności zespotów przestrzennych charakteryzuiacych sie swobodna budowa wewnetrzna. Obrazuje to cykl płócien "Megalopolis" Artura Przebindowskiego ${ }^{47}$, które nie są wi- are stores, a hospital, a school and football pitches. 列

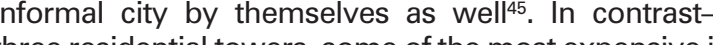
. individual apartment equipped with a large terrace and its own swimming pool, with a fascinating view of the Paraisopolis favela.

Despite the fear they inspire, favelas are beautiful in their own peculiar way-radically beautiful. They are ascinating source of inspiration for literature, the visual arts and film. Their expressive structure brings to and Arizona In both cases we are dealing with terrace buildings, where the roofs of the "older layer" of buildings form the foundations for additional ones. This peculiar spectacularity, apparent chaos and countless multitude of forms, the random densifications and the mixing of shapes, comprise the distinct visual imagery ing flowing and stacking boxes with irregulch borders and the monstrous architecture of tall buildings-forms that are strong and "hard"-generates
an unheard of, almost paralysing contrast, inspiring both fear and a social conscious in the observer on the one hand, while on the other: delight and an aes-

'The favelas' fundamental asset is their structura perception of the cohesion of spatial complexes that are characterised by freeform internal composition. This is depicted in the "Megalopolis" cycle of painting by Artur Przebindowskin, which are not views of a specific city, but indisputably bring to mind South American favelas, inhabited by the poor and tightly only in the colour of the facades, contain the archaic memory of human settlements that have been buit for over five thousand years in Egypt, Mesopotamia or India. The Megalopolises-as Joanna Ciesielska wrote- that have been painted by Przebindowski for many years, are an attempt at visualising the concep of the hive-city, a creation in which cooperation and what makes one survive, instead of the individual and their specific needs ${ }^{48}$.

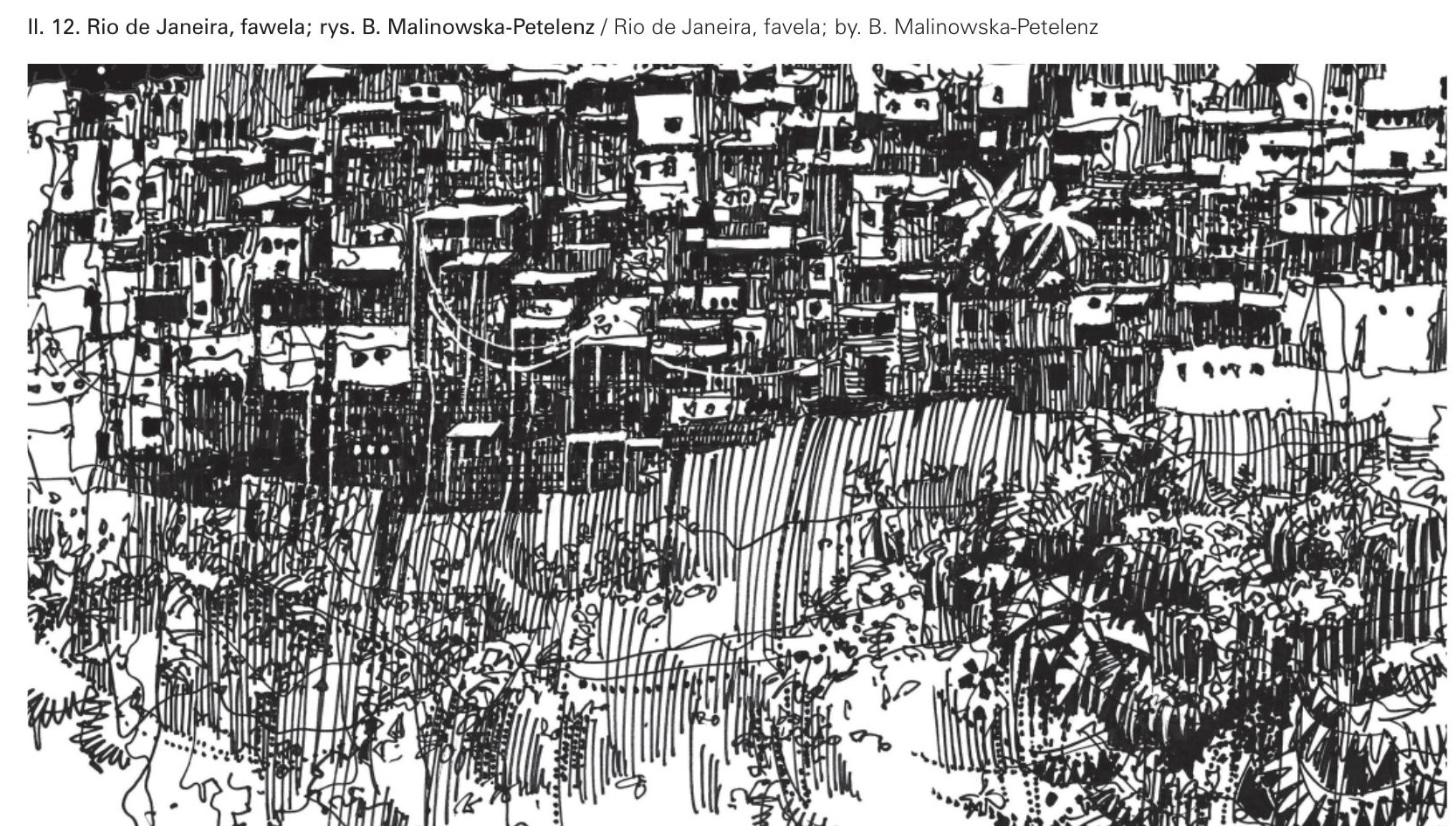

dokiem konkretnego miasta, ale bezsprzecznie budzą skopokrywającymi clasno wzgóza w Rio. Te rózniące się jedynie barwą fasad kompozycje zawierają archaiczną pamięc skupisk ludzkich budowanych od ponad pięciu tysięcy lat w Egipcie, Mezopotamii lub Indiach. Megalopolis - pisze Joanna Ciesielska - malowane przez Przebindowskiego od wielu lat są probą odwzorowania pojęcia miasta-mrow ska, tworu, w ktorym liczy się wspoołpraca i umiejętnośc życia w zbiorowosci, zapewniające przetrwanie, a nie jed-

Zakończenie

Silne kontrasty, kolor i formalny synkretyzm $w$ to podstawowe kategorie, na których opiera się dzisiejszy brazylijskiego pejzażu kulturowego. Kontrasty są siłą i bolączką dzisiejszej Brazylii. Na jedne ulicy współegzystuje ze sobą bieda $z$ bogactwem i ciasnota z zimnym oddechem przestrzeni pustych (a) Narrację skrajności zespolonych w jeden, nowy twór, od lat prowadzi brazylijski artysta Ernesto Neto. Jedna z jego prac - Bestia (2012/49 na stacii Leopoldina w Rio de Janeiro - to wielka podwieszona siatka - wąż. Do kolorowego labiryntu można wejść, dotykać jego struktur, wąchać. Neto świadomie nawiązuje do sztuki użytkowej a nawet designu, gdyż spacerujac w Bestii można mieć skojarzenia $\mathbf{z}$ parkiem rozrywk dla dzieci. Wspomniana wielka siatka została rẹcznie szydełkowana, zatem także na etapie produkcji samego dzieła Neto łączy skrajności - bo rękodzieło to dziśs sztuk drobna, intymna, niewielkoskalowa. Bestia Ernesto Neto to połączenie biomorficznych struktur, pierwotnej pracy rąk i wielkiej skali - tak powszechnej w miastach Brazyli, a jednocześnie tworzy nową jakość - łączącą skrajności. I właśnie w takich kontrastach, wielowątkowych i wielopoziomowych, czasem wspołgrających ze sobą i tworących nową jakosc - a czasem pozostających ze soba w sprzecznoscl, tkwi brazyliska barokowosc i sita, któr tak chętnie portretuje wielki fotograf Sebastiấo Salgado. Pomiędzy dziką naturą a megaskalarnymi miastami, bogactwem i krancową biedą, a nawet między absurdalnie wy sokimi, dumnie stojącymi w rzędach blokami i rozlewając się w niekontrolowany sposob niską zabudowa. Kryje się W kontrastach pomiedzy pelnymi rozmachu "twardymi lniami prosty po a falstymi, definiujacymi zarówno plany, jak i bryly budowli. Znaleźc ja można $w$ przestrzeni po oślepiajacym świattem i pograzonymi w gtebokim cieniu Kontrastuja tu ze soba faktury brutalistyczeych betonów gtadkich białych tynków i drobnych azulejos, kubiczne proste bryły i pustki pomiedzy nimi, a także rytmy żelbetowych konstrukcji z płynną i drapieżna roślinnościa która jest tu ìwiotem bezlitosnym. Falujacy blok mieszkalny Pedregulho Affonsa $E$. Reidy w Rio de Janeiro biegnie miekkimi skretami wzdluż warstwic zbocza, wyraziście kontrastując z sąsiedztwem sztywnych brył osiedla mieszkaniowego. Z kolei malarskie, płynne kompozycje promenady Copacabany i lpanemy, fantastycznie zaprojektowanych przez Roberta Burle Marxa, kontrastuja ze sztywna siatką urbanistyczną krawędzi miasta. I te kontrasty to jes właśnie Brazylia.
Conclusion

Powerful contrasts, colour and formal syncretism are the major categories on which the present-day image the strength and weakness of contemporary Brazil. Poverty and affluence, overcrowding and the breath of empty and monumental spaces coexist on one street. The narrative of extremes combined into one, new creation has been told by Ernesto Neto, a Brazilian artist. One of his works-Bicho (2012)49 at the Leopoldina station in Rio de Janeiro-is a large suspended snake-like inet. The colourful labyrinth smelled. Neto deliberately references applied art and even industrial design, for when we walk with the Beast we can get the impression that we are in a theme park for children. The aforementioned large net was made by hand, therefore Neto combines extremes even during the process of 列 all, handicrafts Bicho is a combination of biomorphic structures, primal manual work and a large scale-which is so common in the cities of Brazil, and creates a new quality of its own at the same time-one tha

It is in these contrasts-which are multi-threaded and each other and create a new quality of their own, or that remain in opposition to one another- that we can find Brazil's Baroque character and the strength that the great photographer Sebastiáo Salgado so often portrays. Between wild nature and mega-scale cities,

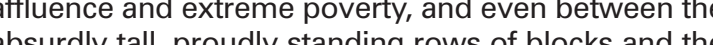
uncontrollably spreading low-height development It hidden in the contrasts between the impressive "hard" straight lines and the wave-like ones that define both the plans and the massings of buildings. We can find it in the spaces between buildings-the enclosed and in deep shedow. The textures of brutalist concten in deep shadow. The textures of brutalist concrete, simple massings and the empty spaces between them contrast with each other, as do the rhythms of concrete structures with fluid and aggressive plant life, which is a called the Pedregulho by Affonso E. Reidy in Rio de its soft curves, expressively contrasting with the nearby rigid massings of a housing development In turn the painterly, fluid compositions of the promenade of Copacabana and Ipanema, fantastically designed by Roberto Burle Marx, contrast with the rigid urban grid of the edge of the city. It is these contrasts that make ENDNOTES

See: Marina Abramoví, James Kaplan, Pokonać mur. Wspomnie
nia, transl. Anna Bernaczyk, Magdalena Hermanowska, Dom Wy dawniczy Rebis, Poznań 2018.
2The Space in Between. Marina Abramobic in Brazil, dir. Marco de

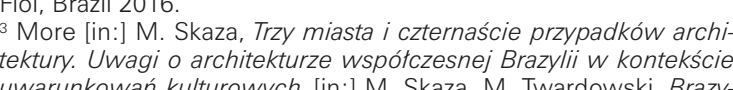

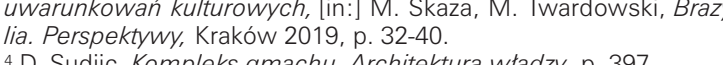
$4 \mathrm{D}$
$5 \mathrm{D}$. Sudjic, Kompleks gmachu. Architektura wtadzy, p. 397
kontrowersiei, Mega pionierzy - mega nadzieje, sukcesy 
PRZYPISY

1Zob. Marina Abramoví, James Kaplan, Pokonać mur. Wspomnienia,
przet. Anna Bernaczyk, Magdalena Hermanowska, Dom Wydawniczy Re pisis, Poznań 2018.
2 Space in bet bispoce in between. Marina Abramović w Brazylii, reż. Marco del Fio,
a Brazylia 2016 . Brazylia 2016.
${ }^{3}$ Więcej [W:] M. Skaza, Trzy miasta i czternaście przypadków architektury.

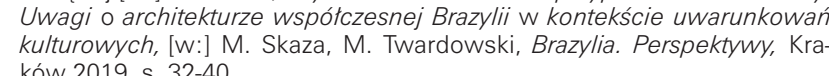

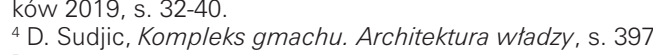
${ }^{5}$ W. Kosiński, Mega pionierzy - mega nadzieje, sukcesy i kontrowersje. S. 23. .
6 Npdtuż arterii St. Norte Onl 1.
7 Proj. Late João Filgueiras Lima, 1968.

8 Oiticaca wychowat sie $w$ jednej z favelas w Rio de Janeiro.
${ }^{9}$ Ines Gebetsroither, Tropicalia I w: I Natural histories. Thaces of the political, pod red. Rainer Fuchs, MUMOK. Wieden 2017, s. 69 . $10 \mathrm{~W}$. Kosiński, Dobro i piekno - miejsca przyjazne cztowiekowi w mia
stach modernistycrnych: idee, projekty, realizacie, s. 60 . 11). Trzeciak, Pryygody archite ktury XX wieku, Warszawa 1974 s. 353. 12. reprezentantem szkoty z Rilo jest nestor brazylijskiego modernizmu
Oscar Niemeyer, którego realizacje charakteryzuja optywowe, miękie 13 reprezentowana gtównie przez Paula Mendesa da Rocha, a takie przez (béton brut), szorstkim i wernakularnym wyrazem swoich budowli${ }_{14}$ Glass House, Morumbi, São Paulo, 1950. 15 Condomínio Edifíicio Louveira, São Paulo, 1946; Faculdade de Arquitetura
e Urbanismo da nniversidade de Säa Paul; CECAP Guarulhos, Săo Paulo. 16
16 Alceu Amoroso Lima's Librarr, Săo Paulo, 1979.
11 Capela Săo Pedro Apóstolo, Sáo Paulo, 1987.

19 Igreja Sáo Bonifácio, São Paulo, 1965.

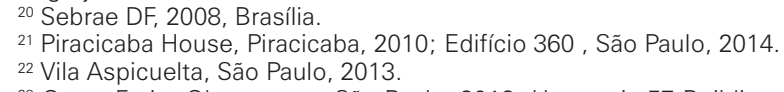
${ }^{23}$ Oscar Freire Observatory, São Paulo, 2012; Harmonia 57 Building, São

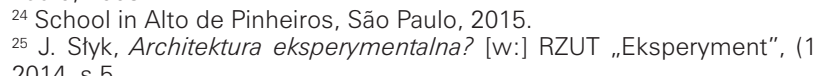
20 Proj. Pedro Paulo de Mello Saraiva, Miguel Julian, 1959.
27 Proj. Jacques Pilon, Gian Carlo Gasperini, 1959. 27 Proj. Jacques Pilon, Gian Carlo
${ }_{28}$ Proj. Daniel Libeskind, 1978.

30 Proj. Königsberger Vannucchi Arruitetos Associados, 2017.
31 Proj. Königsberger Vannucchi Arautetos Associados, 2008 31 Proj. Konnigsberger Vannucchi Arquitetos Associados, 2008.
32 Więcej zob. M. Twardowski, Wieze mieszkalne, Kraków 2017, s. 49-52 32 Wiecej zob. M. Twardowski, Wieze mieszzalne, Kraków 2017, s. 49-52.
33 Wiecej In: I. Rewers, Post-polis., po.cit. . . 266 .
34 H. Grabowska-Patecka, Rio de Janeiro - favele i samba, Architektura \& Biznes nn 7/8, 2001, 5. 52-57.
${ }_{35}$ Schlögel, Karl, 2009, W przestrzeni czas czytamy. O historii cywilizaci, i geopolityce, przet. Izabela Drozodowska, tukasz Musiat, nictwo Poznańskie, s. 288.
36 Twardowski M, Pomiedzy Paulistanos, [w:] M. Skaza, E. Szpakowska,

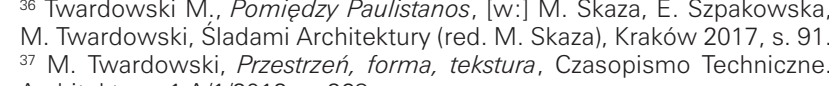
Architekturara, 1-AR/1/2012, s. 2.263.
38 J. McGuirk, Radykalne miasta, s. 42 .

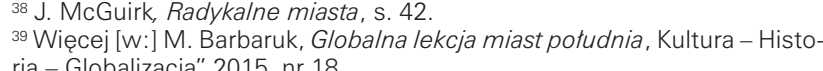

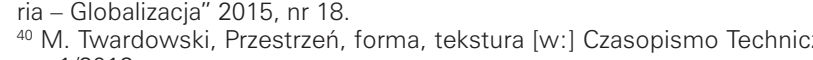

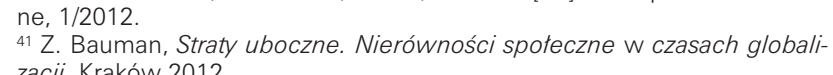
${ }_{42}$ Nagrodzony Ztota Żaba na festivalu Camerimage i nominowany w wzte rech kategoriach do Oscara; , Miasto Boga" zdobyto BAFTE za najepszzy
montaż i British Independent Film Award jako nailepszy film zagraniczny. Film otrzymat również nagrode nowojorskich krytyków oraz nagrodę na

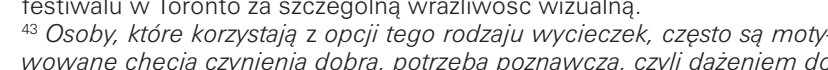
wowane checia czynienia dobra, gotrzeba poznawcza, ccyli dazieniem do
zwiekszenia wiedzy, a takze parciem do redukcii dysonansu poznawczego zwiekszenia wiedzy, a takize parciem do redukcji dysonansu poznawczego
i zmazania poczucia winy, jakie wywotuje w nich ogladanie filmów czy czytanie ksiaziek o fawelach. IW:I A. Skorupa, Z selwy do miasta: psycho-
logiczne studium adaptacii srodowiskowej Mieszkańców Brazylii, Pisma ${ }_{44}^{4}$ Projekt autorstwa A. Tapia, C. Pirondi, R. Otero; więcej [W:] M. Twar

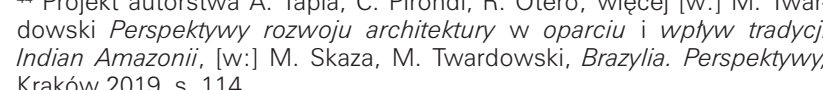

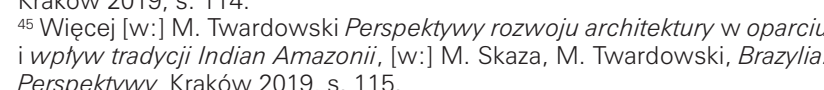

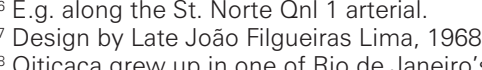
- Ines Gebetsroither, Tropicalia lin:I INaturar ' histories. Traces of the political, ed. Rainer Fuchs, MUMOK, Vienna 2017, p. 69. .
10 W. Kosinski, Dobro i piękno - miejsca przyjazne cztowiekom

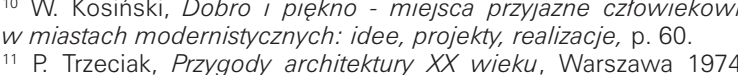
"1. P. Trzeciak, Przygody architektury XX wieku, Warszawa 1974 12 One of the representatives of the Rio school is Oscar Niemeyer.
the nest or of Brazilian modernism, whose projects are characteri-

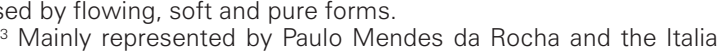
Lina Bo Bardi, it is characterised by raw material finishes (béto ${ }^{4}$ Glass House, Morumbi, São Paulo, 1950. ${ }_{15}^{15}$ Condomínio Edifício Louveira, Sáo Paulo, 1946; Faculdade de
Arquitetura e Urbanismo da Universidade de Săo Paulo; CECAP
Guarulus São Paulo

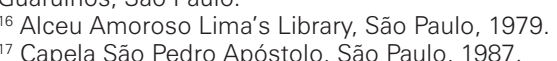

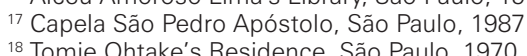

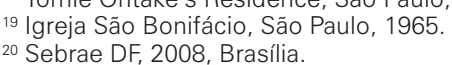

Piracicaba House, Piracicaba, 2010; Edifíicio 360\%, São Paulo. 2. Vila Aspicuelta, Săo Paulo, 2013.

Oscar Freire Observatory, São Paulo, 2012: Harmonia 57 Bül ${ }_{22}^{2}$ School in inlto de Pinheiros, São Paulo, 2015.
${ }^{25}$ J. Styk, Architektura eksper,

J. Styk, Architektura eksperymentalna? [in:] RZUT „Eksperyment " ${ }_{26}$ Design by Pedro Paulo de Mello Saraiva, Miguel Julian, 1959 ${ }_{28}^{2}$ Design by by Jacques Pilon, Gian Carlo Gasperini, 1959

${ }^{29}$ Design by Rino Levi, 1997.

Design by Königsberger Vannucchi Arquitetos Associados, 2017

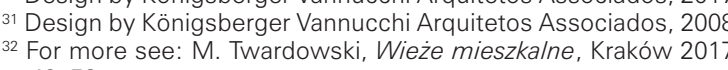

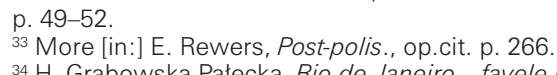

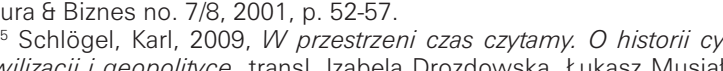
Poznan: Wydawnictwo Poznañskie, p. 288.

36 Twardowski M., Pomiedzzy Paulistanos. lin:] M. Skaza, E. Szpa ków 2011, p. 91.
37 M. Twardowski, Przestrzeń, forma, tekstura, Czasopismo Techniczne. Architektura, 1-A/1/2012, p. 263.
$38 \mathrm{~J}$. McGuirk, Radykalne miasta, p. 42.

More [in:I M. Barbaruk, Globalna lekcja miast potudnia, Kultura4istoria - Globalizacia" 2015 , no. 18.
00 M. Twardowski, Przestrzen, forma, tekstura [in:] Czasopismo Techniczne, 1/2012. Z. Bauman, Straty uboczne. Nierównosci spoteczne w czasach
globalizacji, Kraków 2012. ${ }_{42}$ Awarded the Golden Frog at the Camerimage Festival and no-
minated for the Oscars in four categories; "City of God" won the minated for the Oscars in four categories; "City of God" Won the
BAFTA for best editing and the British International Film Award as the best foreign picture. The film also received the New York cri-
tics' award and the Toronto film festival award for particular visual lics' award and the Toronto film festival award for particular visua
sensitivity.

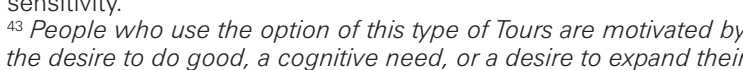
the desire to do good, a cognitive need, or a desire to expand their
knowledge, as well as the need to reduce cognitive dissonance and erase the feeling of guilt caused by reading books or watching films
about favelas lin:I A. Skorupa, Z selwy do miasta: psychologiczne
studium adaptacij sirodowiskowej Mieszkańców Brazyli, Pisma Hustudium adaptaciji środowiskowej Mieszkańcow Brazyli, Pisma He-
manistyczne, v.10, p. 161. ${ }^{4}$ Design by A. Tapia, C. Pirondi, R. Otero; more [in:] M. Twardow-
ski Perspektywy rozwoju architektury w oparciu i wptyw tradyc

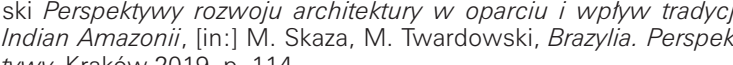
tywy, Kraków 2019, p. 114 .
${ }_{5}^{5}$ More lin:] M. Twardowski Perspektywy rozwoju architektury

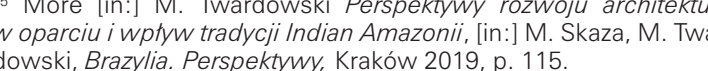
${ }^{66}$ More [in:] B. Malinowska-Petelenz, Dziedzictwo modernizmu.
W poszukiwaniu lokalnej tożsamości, [in:] B. Malinowska-Petelenz

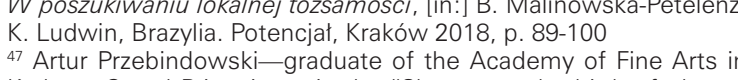
rakow, Grand Prix winner in the "Shower - the birth of pleasu
re" painting competition in Bad Zwischenahn in Germany in 1998 winner of the Grand Prix of the Minisister of Culture and National He
wantion szukivaniu Iokalnej tozsamoscoi, [w:] B. Malinowska-Petelenz, K. Ludwin.

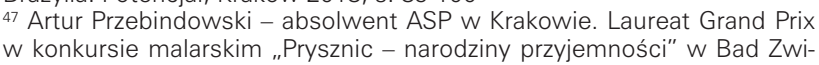

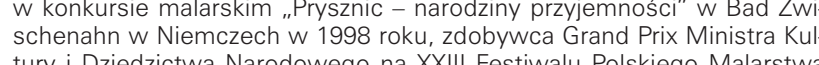

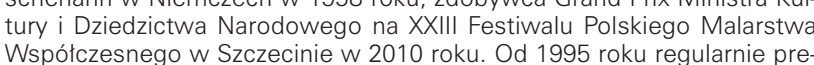
Wspótczesnego w Wrczecinie $w 2010$ roku. Od 1995 roku regularnie pre
zentujie swoje malarstwo na licznyych wystawach, festiwalach malarstwa

it targach sztukk na calymm świecie.e.
48 J. Ciesielska, tekst kuratorski do wystawy Piekni malarze o pięknie, Galeria 12 W Cieszynie, maj 2017, https: //Mww. facebook-.con

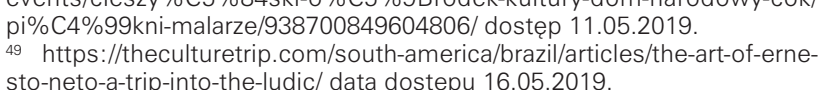

LITERATURA

[1] Abramović M., Kaplan J., Pokonać mur. Wspomnienia, przet. Anna
Bernaczyk, Magdalena Hermanowska, Dom Wydawniczy Rebis, Pozznan 21 Barbaruk M Globaln lekcia miest potudnia, Kutura - Historia - GIobalizacja" 2015, nr 18.
[3] Bauman Z., Straty uboczne. Nierównoości spoteczne w czasach globa

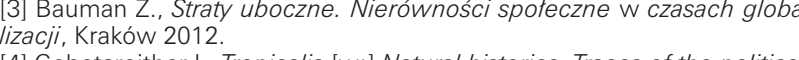
[4] Gebetsroither I., Tropicalili [ [W:] Natural histories. Traces of the pollitical,
pod red. Rainer Fuchs, MUMOK, Wieden 2017, s. 69 . pod red. Rainer Fuchs, MUMOK, Wiedeń 2017, s. 69.
55] Grabowska-Patecka H., Rio de Janeiro - favele isamba, Architektura \&

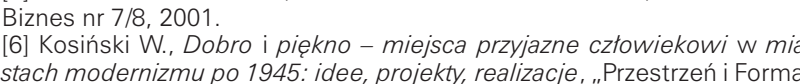
nr 20, 2013

[7] Kosiński W. Mega pionierzy - mega nadzieje, sukcesy i kontrowersje.
Przzestreńn i Forma" nr 13, 2010.

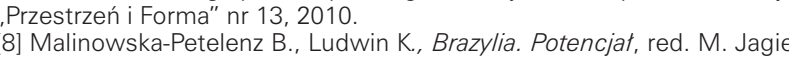
to-Kowalczyk, wyd. PK, Kraków 2018,
[9] Malinowska-Petelenz Beata, Twardowski M., Miasto/nie-miasto. Brasslila, Teka Komisji Urbanistyki A Architektury. T. 46. 2018.

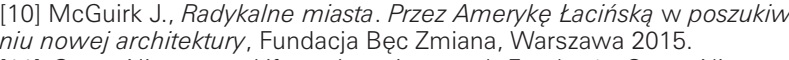

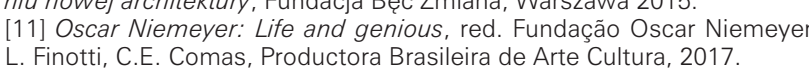
12] Rewers $E$., Post-polis. Wstęp do filozofii ponowoczesnego miasta,

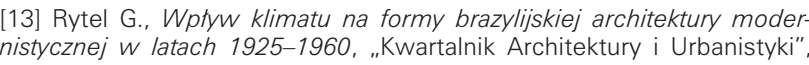

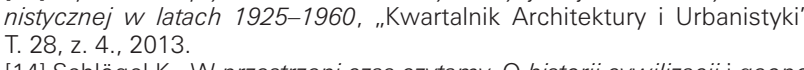

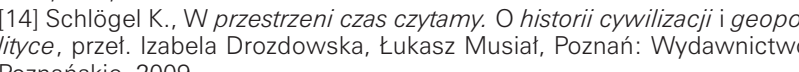
[15] Siedlecki B., M

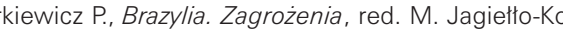

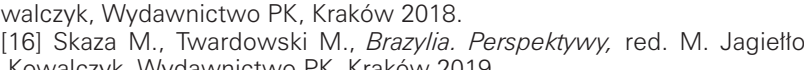
17] Skorupa A., Z seliny do miasta: psychologiczne studium adaptacii śro dowiskowej Mieszzkńców Brazylii, Pisma Humanistyczne, t.10.

[19] Sudjic D., Jezyk miast, Kraków 2017.

21] Trzeciak P., Przygody architektury XX wiraku Warszawa 1974. [22] Twardowski M., Brasilitia - urban and architectural experiment after

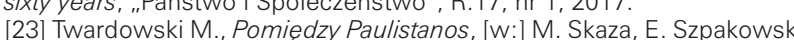

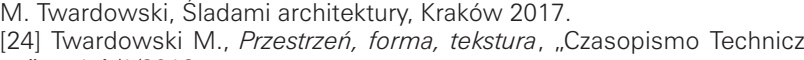

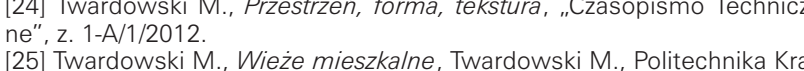
[25] Twardowski M., Wieże mieszkalne, Twardowski M., Politechnika Kra-
kowska im. T. Kościuszki, Kraków 2017. Żródta:

Ciesieliska J, tekst kuratorski do wystawy Piekni malarze o pięnnie, Ga

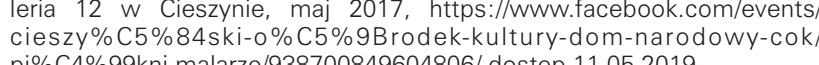
hiltps://theculturetrip.com/south-americal/brazil/articles/the-art-of-ernesto-neto-a-trip-into-the-ludic/ data dosteppu 16.05.2019. Space in between. Marina Abramovic w Wrazylii, reż. Marco del Fiol, Bra-
zylia 2016 .

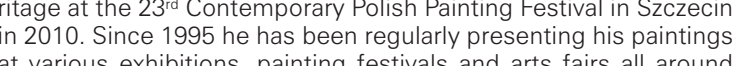

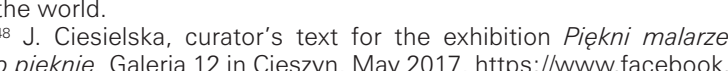

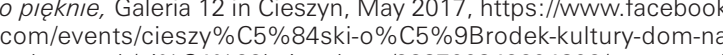
rodowy-cok/pi\%C4\%99kni-malarz//938700849604806/ accessed
11.05 .2019 49 https://theculturetrip.com/south-america/brazil//articles/the-art-
-of-ernesto-neto-a-trip-into-the-Iudic/ accessed 16.05.2019.

\section{BIBLIOGRAPHY}

(1) Abramović M., Kaplan J., Pokonać mur. Wspomnienia, transl.
Anna Bernaczyk, Magdalena Hermanowska, Dom Wydawniczy Rebis, Poznań 2018 .
2] Barbaruk M. Globalna lekcja miast potudnia, ,Kultura - Historia [3] Bauman Z., Straty uboczne. Nierówności spoteczne w czasach globallzzacl, Krakow 2012. (4) Gebetsroither l., Iropicallia lin:! Natural histories. Traces of the
political, ed. Rainer Fuchs, MUMOK, Vienna 2017, p. 69 . [5] Grabowska-Patecka H., Rio de Janeiro - favele i samba, Archilektura \& Biznes no. 7/8, 2001.
[6] Kosiński W., Dobro i piekno

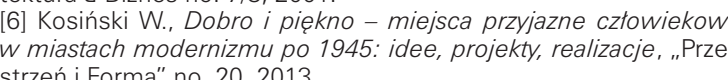
strzeń i Forma" no. 20, 2013.
[7] Kosinśski W., Mega pionierzy - mega nadzieje, sukcesy i kontro-

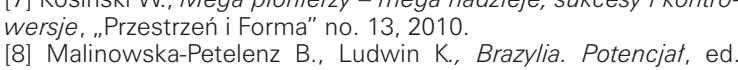
(8) Malinowska-Petelenz B.', Ludwin K, Brazylia. Potencjat, ed
M. Jagielto-Kowalczyk, wyd. PK., Krakón'w 2018. [9] Malinowska-Petelenz Beata, Twardowskki M., Miasto/nie-miasto. Brasslia, Teka Komisji Uranaistyki i Architektury, V. 46, 2018.
[10] McGuirk J., Radykalne miasta. Przez Amernke tacinska w poszukiwaniu nowej architektury, Fundacja Bęc Zmiana, Warszawa
2015 .
1111 Oscar Niemeyer: Life and genious, ed. Fundacãa Oscar Nie-
meyer, L. Finotti, C.E. Comas, Productora Brasileira de Arte Cultura, 2017. E. Post:polis. Wstęp do filiozofii ponowoczesnego mia sta, Kraków 2005 .
131 Rytel G. Wotyw klimatu na formy brazylijskiej architektury modernistycznej w latach 1925-1960, , Kwartalnik Architektury i Urba[14] Schlögel K., W przestrzeni czas czytamy. O historii cywilizacij!
geopolityce, transl. Izabela Drozdowska, Łukasz Musiat, Poznan:

(15] Siedlecki B.. Markiewicz P. Brazylia. Zagroizenia, ed. M. Jagietto-Kowalczyk, Wydawnictwo PR, Kraków 2018.
[16] Skaza M., Twardowski M. Brazylia, Perspektyw, ed. M. Jagiet[17] Skorupa A., Z selwy do miasta: psychologiczne studium adap-
tacij srodowiskowej Mieszkańców Brazylii, Pisma Humanistyczne. (18] Styk J. Architektura eksperymentalna? [in:] RZUT „Ekspery

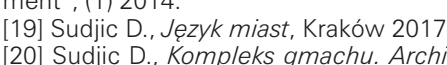
211] Ireciak. P., Przygody architektury XX wieku, Warszawa 1974.
221 Twardowski M. Braslilia - urban and architectural experime

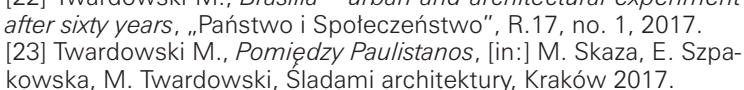
kowska, M. Twardowski, Sladami architektury, Krakow 2017.
[24] Twardowski M. Przestrzeń, forma, tekstura, "Czasopismo
Techniczne", b. 1-A11/2012. [25] TTardooskki M. Wi Wize mieszkalne, Twardowski M., Politechni-
ka Krakowska im. T. Kościuszki, Kraków 2017.

Sources:
Ciesielska J, curator's text for the exhibition Pieknni malarze o piek-
nie, Galeria 12 in Cieszyn, May 2017, https://www.facebook.com/ nie, Galeria 12 in Cieszyn, May 2017, hitps:// wwww.tacebook.cor

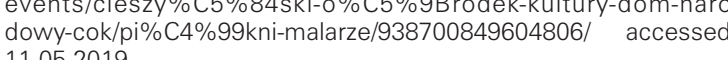
https://theculturetrip.com/south-america/brazil/articles/the-art-ofSpace in between. Marina Abramovic w Brazylii, dir. Marco del
Fiol, Brazil 2016 . 